\title{
ASESMEN MATA KULIAH KANJI DI JURUSAN PENDIDIKAN BAHASA JEPANG
}

\author{
K. A. Paramitasari ${ }^{1}$, D. M. S. Mardani ${ }^{2}$, G. S. Hermawan ${ }^{3}$ \\ Jurusan Pendidikan Bahasa Jepang \\ , Universitas Pendidikan Ganesha \\ Singaraja, Indonesia \\ e-mail: paramitaaayu@gmail.com \\ desak.mardani@undiksha.ac.id satya.hermawan@undiksha.ac.id
}

\begin{abstract}
Abstrak
Penelitian ini bertujuan untuk menganalisis (1) model asesmen mata kuliah Kanji Shokyuu, Kanji Chukyuu, dan Kanji Jokyuu di Jurusan Pendidikan Bahasa Jepang dilihat dari bentuk tes dan latihan yang digunakan oleh pengajar pada mata kuliah Kanji ini, (2) perbedaan model asesmen antara mata kuliah Kanji Shokyuu, Kanji Chukyuu, dan Kanji Jokyuu, (3) faktor yang menentukan pilihan model tes yang digunakan pengajar dalam mata kuliah Kanji. Subjek penelitian ini adalah tiga dosen pengajar Kanji di lingkungan Jurusan Pendidikan Bahasa Jepang. Pengumpulan data dilakukan dengan motode dokumentasi, dan wawancara, kemudian dianalisis dengan cara deskriptif kualitatif. Hasil penelitian ini adalah (1) Ketiga dosen pengajar Kanji di Jurusan Pendidikan Bahasa Jepang lebih banyak menggunakan model tes formatif. Namun dosen pengajar Kanji Chukyuu juga menggunakan model soal melengkapi (Completion test) pada salah satu bentuk tes yang digunakannya. Dan dosen pengajar Kanji Jokyuu menggunakan model tes objektif dalam bentuk tes teka-teki silang. (2) Perbedaan asesmen antara mata kuliah Kanji Shokyuu, Kanji Chukyuu dan Kanji Jokyuu terdapat pada isi dari masing-masing mata kuliah dan bobot yang dimiliki sesuai dengan silabus dan RPP yang digunakan masing-masing dosen pengajar Kanji . (3) Faktor penentu model tes yang digunakan dosen pengajar Kanji ada dua faktor yaitu, faktor umum dan faktor khusus. Faktor umum yaitu faktor dari silabus dan RPP yang ada di Jurusan Pendidikan Bahasa Jepang, sedangkan faktor khusus terdiri dari lima aspek penting, aspek-aspek tersebut yaitu aspek keindahan menulis Kanji , cara baca, urutan Kanji, menulis arti Kanji , menulis Kanji dengan baik dan benar, dan melengkapi soal rumpang.
\end{abstract}

Kata kunci: Bahasa Jepang, Model Tes, Perbedaan Asesmen Mata Kuliah Kanji , Faktor Penentu Model Tes.

$$
\text { 要旨 }
$$

本研究の目的は、1）日本語教育学科における漢字授業の評価のモデルは教師が使用するテストのモ デルと漢字練習 2）初級レベル漢字授業と他の漢字授業の評価の差異 3 ) 教師が

漢字授業に使用するテストのモデル選択を決める要因を明らかにすることである。研究の対象は、日 本語教育学科の 3 名の教師である。調査方法は、観察、インタビュー及び文献調查である。収集した データは定性的記述法により分析した。分析した結果、1）３名の教師の中で、ほとんど形成期テス 卜を使用した。しかし、中級漢字を教えている教師は完了テストを使用する。目的は 学生は漢字の意味を理解して覚えられることである。また、上級漢字に教えている教師が、他のテス トのモデルを使用している。それはクロスワードパズルテストである、目的は

学生は漢字の意味を理解して覚えられることである。形成期テストは

学生の漢字能力はどのぐらいか、測定して、明らかにすることである。

2 ）初級、中級、上級レベル漢字授業の評価の差異は 授業内容と 教師が 使用してるシラバス、授業計画である、3）教師が

漢字授業に使用するテストのモデル選択を決める要因は一般要因と特殊要因の二つである。一般的な 要因は、日本語教育学科における シラバスと 授業計画である。特殊要因は

五つの重要な側面である。それは、漢字の美しさ、漢字の読み方、漢字の書き順、漢字の意味、適当 に漢字を書く、穴埋めの問いを完成することである。

キーワード : 日本語、テストのモデル、漢字授業の査定の

相違点、テストのモデル選択を決める要因

\section{Pendahuluan}


Bahasa Jepang merupakan salah satu bahasa asing yang sudah banyak dipelajari dalam dunia pendidikan saat ini. Menurut Japan Foundation (2004) mencatat perkembangan pendidikan bahasa Jepang di Indonesia mencapai 432 lembaga sekolah menengah atas, dan 78 lembaga perguruan tinggi. Untuk dapat mempelajari bahasa Jepang ada beberapa hal yang harus dipelajari dan dipahami yaitu hatsuon (ucapan), moji (huruf), goi (kosakata), bunpo (tata bahasa), hyogen (ekspresi). Kindaichi (2002) menyatakan lima hal tersebut termasuk dalam karakteristik-karakterisik bahasa Jepang yang utama. Di dalam perkuliahan bahasa Jepang Jurusan Pendidikan Bahasa Jepang Universitas Pendidikan Ganesha, lima karakteristik bahasa Jepang seperti, hatsuon (ucapan), moji (huruf), goi (kosakata), bunpo (tata bahasa) dan hyogen (ekspresi) tertuang dalam berbagai mata kuliah yang ditawarkan oleh Jurusan Pendidikan Bahasa Jepang seperti mata kuliah Kaiwa (berbicara), Bunpo (tata bahasa), Chokkai (mendengarkan), Sakubun (mengarang), Dokkai (membaca), maupun Kanji (menulis).

Diantara mata kuliah tersebut dilihat dari hasil wawancara dengan mahasiswa dalam kurun waktu 2 minggu (pada pertengahan bulan april) ditemukan bahwa mata kuliah Kanji menjadi salah satu problematika pada mahasiswa Jurusan Pendidikan Bahasa Jepang Universitas Pendidikan Ganesha. Hal ini disebabkan karena rata-rata 75\% mahasiswa masih merasa kesulitan dalam mempelajari mata kuliah Kanji ini.

Dari hasil wawancara tersebut, sebagian besar mahasiswa mengeluhkan sulitnya belajar Kanji karena bentuk huruf Kanji yang rumit dan membuat mahasiswa bahasa Jepang tersebut merasa tidak memiliki semangat dalam belajar Kanji . Alasan lainnya yang dikemukakan oleh mahasiswa yaitu, karena huruf Kanji memiliki dua cara baca yang berbeda yaitu On Yomi dan Kun Yomi. Sehingga tidak jarang membingungkan pembelajar atau mahasiswa saat mempelajari Kanji .

Meskipun demikian Kanji merupakan mata kuliah bersyarat yang mewajibkan mahasiswa untuk lulus mata kuliah Kanji ini. Kanji sangat penting dan harus dikuasai karena mempelajari dan mengerti Kanji dapat membantu dalam pembelajaran bahasa Jepang lainnya seperti, Bunpo (tata bahasa), Dokkai (membaca), Sakubun (mengarang) dan yang lainnya.

Dilihat dari kesulitan yang dirasakan oleh mahasiswa dalam mata kuliah Kanji ini, dosen pengajar mata kuliah Kanji mencari cara dan berupaya untuk memahami bagianbagian sulit dalam mata kuliah Kanji yang diajarkan dan mencari cara agar dapat membantu mahasiswa dalam mengatasi masalah tersebut, salah satunya yang dapat berdampak pada nilai akhir mahasiswa tersebut. Salah satu cara yang dilakukan dosen pengajar mata kuliah ini yaitu dengan memperbaharui cara yang digunakan dalam melakukan penilaian dalam mata kuliah Kanji . Penilaian dalam mata kuliah Kanji yang awalnya difokuskan pada urutan Kanji kemudian ditambah dengan memberikan tes yang dapat menilai atau menguji pengetahuan mahasiswa tentang makna Kanji . Perubahan jenis soal yang dibuat dosen untuk mahasiswa dalam mata kuliah ini memperlihatkan bahwa dosen pengajar sudah melakukan perubahan untuk mengatasi permasalahan yang dialami mahasiswa dalam belajar Kanji , dengan harapan dapat membantu mahasiswa untuk memahami makna Kanji dan mahasiswa dapat lulus dalam mata kuliah Kanji ini.

Hal inilah yang mendorong peneliti untuk melakukan penelitian terkait asesmen mata kuliah Kanji . Dengan penelitian ini dapat dilihat model-model asesmen yang dibuat oleh dosen pengajar Kanji untuk diberikan kepada mahasiswa Jurusan Pendidikan Bahasa Jepang. Sebelumnya terdapat dua penelitian tentang asesmen yaitu, Penelitian yang menyimpulkan bahwa penilaian harus mengukur tujuan yang ingin dicapai sesuai dengan apa yang diinginkan, jika ingin menilai keterampilan maka bentuk yang dipilih penilaian kinerja dengan alat yang tepat, namun alat yang digunakan sesuai dengan tingkat kemampuan dan kurikulum yang dikehendaki.

Namun pada penelitian ini, peneliti mencoba untuk melakukan penelitian tentang asesmen mata kuliah Kanji di Jurusan Pendidikan Bahasa Jepang UNDIKSHA dilihat dari segi model asesmen yang digunakan setiap pengajar guna mengetahui cara evaluasi pengajar tersebut terkait pembelajaran Kanji . Penelitian ini memberikan gambaran tentang 
bagaimana model asesmen yang digunakan pengajar mata kuliah Kanji dalam mengukur kemampuan mahasiswa pembelajar Kanji .

\section{Metode}

Berdasarkan fokus penelitian yang sudah dijabarkan dan ditinjau dari segi prosedur dan pola yang ditempuh peneliti, maka penelitian ini termasuk dalam penelitian deskriptif kualitatif. Menurut Sujana (dalam Sundari, 2001), penelitian deskriptif merupakan penelitian yang mendeskripsikan suatu gejala, peristiwa, dan kejadian yang terjadi pada saat sekarang ini. Menurut Sugiyono (2013), metode penelitian pada dasarnya merupakan cara ilmiah untuk mendapatkan data dengan tujuan dan kegunaan tertentu. Berdasarkan hal tersebut terdapat empat kunci yang perlu diperhatikan yaitu cara ilmiah, data, tujuan, dan kegunaan. Tujuan peneliti menggunakan penelitian deskritif kualitatif karena data-data yang di peroleh berupa data-data penilaian, dan silabus, yang akan dianalisis dengan memaparkan hasil yang diperoleh dari pengamatan hasil penelitian dengan diuraikan dalam kata-kata bukan dalam bentuk bilangan atau statistik.

Subjek penelitian adalah orang yang dikenai tindakan (Wendra, 2013:53). Subjek penelitian adalah himpunan elemen yang didapat berupa orang, organisasi atau barang yang diteliti (Supranto, 2000:21). Subjek dari penelitian ini adalah dosen-dosen pengajar mata kuliah Kanji di lingkungan Jurusan Pendidikan Bahasa Jepang.

Pada penelitian ini, akan dilakukan secara bertahap yang direncanakan. Dalam proses pengumpulan data, peneliti mengunakan langkah-langkah sebagai berikut, Membuat instrumen yang dibutuhkan untuk penelitian seperti transkip wawancara, mengumpulkan data-data penelitian, menganalisis data, mendeskripsikan dan merumuskan data penelitian.

Pengumpulan data juga dilakukan dengan proses wawancara dan dokumentasi. Dimana wawancara dilakukan di Jurusan Pendidikan Bahasa Jepang khususnya pada kelas-kelas yang mendapatkan mata kuliah Kanji. wawancara dlakukan untuk mendeskripsikan model asesmen yang digunakan dalam penilaian mata kuliah Kanji. Wawancara dilakukan secara langsung kepada mahasiswa yang telah mendapatkan mata kuliah Kanji untuk mengetahui data awal tentang mata kuliah ini. Wawancara merupakan sebuah dialog yang dilakukan oleh pewawancara (interviewer) untuk memperoleh informasi dari terwawancara (interviewer) (Arikunto,2006:155). Tujuan dari dilakukannya wawancara adalah untuk mendapatkan keterangan atau pendirian secara lisan dari seorang responden dengan bercakap-cakap berhadapan dengan orang itu. Wawancara juga dilakukan kepada dosen pengajar terkait dengan asesmen yang digunakan dalam mengukur kemampuan mahasiswa dalam mata kuliah Kanji ini. Selain itu peneliti juga akan mengumpulkan datadata berupa data yang dimiliki oleh dosen terkait asesmen yang dilakukan pada mata kuliah Kanji .

Pada penelitian ini, proses pengumpulan data dan analisis data dilakukan bersamaan. Oleh sebab itu, analisis akan dilakukan pada saat proses pengumpulan data atau segera setelah data-data penelitian terkumpul. Setelah data diperoleh, dan dilanjutkan dengan menganalisis data tersebut. Berdasarkan penelitian yang digunakan adalah data analisis deskritif, maka deskripsi data ini akan disusun dan dikelompokan sesuai dengan data yang ada, sehingga dapat memberikan gambaran nyata kepada responden terhadap penelitian dengan menggunakan teori yang dipakai landasan.

Teknik analisis data pada penelitian ini menggunakan dua teknik (Miles dan Huberma, 1992:15-19) yaitu. Pengumpulan data dan Analisis deskriptif. Pengumpulan data yaitu pengumpulan data di lokasi penelitian dengan melakukan observasi, wawancara dan dokumentasi dengan menentukan strategi pengumpulan data yang di pandang tepat dan untuk menentukan fokus serta pendalaman data pada proses pengumpulan data berikutnya. Sedangkan analisis deskriptif bertujuan untuk memberikan deskripsi mengenai subjek penelitian berdasarkan data yang sudah diperoleh.

\section{Hasil dan Pembahasan}

Model Asesmen Mata Kuliah Kanji di Jurusan Pendidikan Bahasa Jepang, dilihat Dari Bentuk Tes dan Latihan Yang Digunakan Pengajar Kanji. 
Di Jurusan Pendidikan Bahasa Jepang terdapat tiga dosen pengajar Kanji. Dosen pengajar Kanji memiliki model-model asesmen yang sesuai dengan silabus yang pengajar miliki. Adapun model-model asesmen yang digunakan dosen pengajar Kanji sebagai berikut.

Dosen pengampu mata kuliah Kanji Shokyuu (Hyouki 2), dalam penilaian Kanji menggunakan model tes formatif dalam tiga bentuk soal, seperti pada soal uraian pertama dosen pengajar menggunakan soal yang meminta mahasiswa untuk membaca Kanji sesuai dengan cara baca Onyomi dan Kunyomi nya, tujuan soal ini agar mahasiswa mengetahui dan memahami cara baca Kanji yang dipelajari. Pada soal uraian kedua mahasiswa diminta mengisi urutan penulisan Kanji yang benar. Hal ini bertujuan agar mahasiswa bisa lebih memahami secara mendalam lagi tentang Kanji dalam urutan penulisan Kanji yang benar. Pada uraian yang ketiga mahasiswa diminta menjawab cara baca kosakata Kanji, tujuannya agar mahasiswa mampu memahami makna Kanji yang dipelajarinya. Ketiga bentuk tes yang digunakan dosen pengajar ini menggunakan model tes formatif. Tes formatif adalah tes untuk mengetahui dan mengukur hasil belajar mahasiswa, sudah sejauh mana peserta didik menguasai pelajaran yang sudah diberikan. Model tes ini digunakan agar dosen pengajar dapat mengukur sudah sejauh mana mahasiswa atau pembelajar memahami mata kuliah Kanji yang sudah dipelajari.

Dosen pengampu mata kuliah Kanji Chukyuu (Kanji 1) dalam model-model soal yang digunakan pengajar mata kuliah Kanji ini berdasarkan teori yang dikemukakan oleh Sudijono (2009), menggunakan model tes formatif yang memiliki tujuan untuk mengetahui sudah sejauh mana mahasiswa memahami pelajaran Kanji yang sudah diberikan. Pada soal romawi I dosen pengampu mata kuliah Kanji ini menggunakan soal urutan Kanji, soal ini memiliki model dan bentuk yang serupa dengan dosen pengampu mata kuliah Kanji yang pertama. Hal ini disebabkan karena tujuan pembelajaranya sama. Pada soal romawi II yaitu cara baca Kunyomi dan Onyomi, tujuannya agar mahasiswa dapat mengingat cara baca Kanji yang telah diajarkan. Pada soal romawi III yaitu soal menjawab cara baca Kanji dimana bertujuan agar mahasiswa memahami arti dari Kanji-Kanji yang telah dipelajari. Bentuk soal pada romawi I sampai dengan romawi III sama dengan bentuk soal yang digunakan dosen pengampu mata kuliah Kanji yang pertama. Hal ini disebabkan karena tujuannya sama. Perbedaannya terdapat pada soal di romawi IV yaitu soal rumpang atau lebih tepatnya model tes melengkapi (Completion test). Tes melengkapi adalah salah satu bentuk tes dimana butir-butir soalnya berupa satu kalimat dimana bagian-bagian tertentu yang dianggap penting dikosongkan dan peserta didik diminta untuk mengisi bagian yang kosong tersebut. Tes ini bertujuan untuk membuat mahasiswa melatih kemampuan mengingat dan memahami Kanji yang telah dipelajari. Melalui soal model rumpang ini, lebih membuat mahasiswa untuk mengingat arti Kanji dan juga membuat mahasiswa tersebut mampu mengingat arti dan makna Kanji yang dipelajarinya.

Dosen pengampu mata kuliah Kanji jukyuu (Kanji 2), dalam model-model tes yang digunakan dosen pengajar Kanji ini berpatokan pada silabus yang ada, tujuannya agar mahasiswa mampu memahami makna dan arti setiap Kanji yang dipelajari. Pada soal bagian pertama dosen pengajar Kanji ini menggunakan bentuk soal mengubah Kanji ke huruf hiragana, tujuannya agar pembelajar Kanji dapat membaca dengan benar Kanji -Kanji yang telah dipelajari. Pada bagian kedua dosen pengajar ini menggunakan model soal mengubah Kanji dari huruf hiragana ke bentuk Kanji nya, soal ini bertujuan untuk melihat seberapa besar kemampuan pembelajar Kanji dalam memahami arti dari Kanji tersebut. Kedua bentuk tes yang sudah dipaparkan tersebut yaitu bentuk soal mengubah Kanji ke huruf hiragana dan bentuk soal mengubah huruf hiragana ke dalam huruf Kanji adalah model tes formatif yang memiliki tujuan untuk mengukur sudah sejauh mana peserta didik memahami pelajaran Kanji yang sudah diberikan. Pada bagian ketiga menggunakan bentuk soal teka-teki dimana soal teka-teki ini sama seperti mengisi soal teka-teki silang namun yang membedakan adalah soal yang digunakan adalah kosakata Kanji yang ditulis dalam bentuk huruf hiragana dan jawabannya disusun dalam kotak teka-tekinya dalam bentuk Kanji , seperti contoh soal 日本maka pada kotak teka-teki terdapat dua kotak kosong yang sesuai dengan pertanyaan tersebut, tujuannya agar pembelajar Kanji mampu mengingat dan memahami arti Kanji tersebut. Model tes seperti ini disebut dengan model tes objektif, ini 
berarti model tes yang terdiri dari butir-butir soal yang dapat dijawab oleh peserta didik dengan memilih salah satu atau lebih jawaban diantara beberapa kemungkinan yang telah dipasangkan dengan masing-masing butir soal. Menjawabnya dengan cara menuliskan katakata atau simbol-simbol tertentu pada ruang yang sudah disediakan. Namun dosen pengajar Kanji ini telah memodifikasi model soal yang digunakan sesuai dengan tujuan yang ingin dicapai yaitu agar pembelajar lebih memahami dan mengingat Kanji dengan baik.

Dari model-model tes yang digunakan oleh para dosen pengajar Kanji yang telah dipaparkan dapat dilihat ketiga dosen pengajar Kanji menggunakan model tes formatif, namun dosen pengajar Kanji Chokyuu (Kanji I) juga menggunakan model tes melengkapi (Completion test) pada salah satu bentuk soal yang digunakan, dan dosen pengajar Kanji Jukyuu menggunakan juga model tes objektif yaitu pada bentuk soal teka-teki. Model tes yang digunakan berpatokan pada silabus mata kuliah Kanji di Jurusan Pendidikan bahasa Jepang. Dari ketiga dosen pengajar Kanji di Jurusan Pendidikan Bahasa Jepang lebih banyak menggunakan model tes formatif, Seperti contohnya dosen pengajar Kanji Shokyuu, dosen pengajar Kanji Chokyuu, dan dosen pengajar Kanji Jukyuu menggunaka model yang formatif dengan tujuan untuk mengetahi dan mengukur kemampuan mahasiswa dalam mata kuliah Kanji tersebut. Dosen pengajar Kanji Chokyuu juga menggunakan model tes melengkapi tujuanya agar mahasiswa bisa lebih mengingat arti dan makna Kanji yang telah dipelajari. Dosen pengajar Kanji Jukyuu juga menggunakan model tes objektif yang sudah dimodifikasi kedalam bentuk tes teka-teki silang dimana tujuannya untuk mengukur kemampuan mahasiswa dalam mengingat arti da makna Kanji yang telah dipelajarinya.

Model asesmen mata kuliah Kanji di Jurusan Pendidikan Bahasa Jepang dilihat dari model tes yang digunakan dosen pengajar Kanji, sesuai dengan hasil wawancara yang dilakukan model tes yang digunakan dosen pengajar Kanji memang harus sesuai dengan silabus yang telah tersedia. Model soal yang digunakan pun memliki bobot dan tujuannya masing-masing. Tujuan model tes sesuai dengan teori yang dikemukakan oleh Arikunto (2006) yaitu, memberikan umpan balik kepada pengajar untuk memperbaiki proses pembelajaran, secara sumatif sebagai alat penentu nilai hasil belajar mahasiswa, secara diagnostik yang digunakan sebagai penilaian dimana untuk dapat mengetahui kelemahan pembelajar, bertujuan untuk mengukur keberhasilan agar dapat mengetahui sudah sejauh mana pembelajar memahami suatu program pembelajaran yang sudah diterapkan. Mata kuliah Kanji merupakan mata kuliah yang sulit untuk dipelajari maka dari itu dosen pangajar Kanji melakukan inovasi dan pembaharuan dalam model-model asesmen yang digunakan untuk mengukur kemampuan mahasiswa pembelajar Kanji. Model tes yang digunakan masing-masing dosen pengajar mata kuliah Kanji memiliki bobot tersendiri sesuai dengan tingkatan Kanji yang diajarkan. Model tes dan latihan yang digunakan pengajar Kanji sesuai dengan materi ajar yang sudah diajarkan dan diharapkan mampu meningkatkan motivasi pembelajar Kanji dalam belajar Kanji.

Model asesmen mata kuliah Kanji di Jurusan Pendidikan Bahasa Jepang dilihat dari model tes yang digunakan dosen pengajar Kanji, sesuai dengan hasil wawancara yang dilakukan model tes yang digunakan dosen pengajar Kanji memang harus sesuai dengan silabus yang telah tersedia. Model soal yang digunakan pun memliki bobot dan tujuannya masing-masing. Tujuan model tes sesuai dengan teori yang dikemukakan oleh Arikunto (2006) yaitu, memberikan umpan balik kepada pengajar untuk memperbaiki proses pembelajaran, secara sumatif sebagai alat penentu nilai hasil belajar mahasiswa, secara diagnostik yang digunakan sebagai penilaian dimana untuk dapat mengetahui kelemahan pembelajar, bertujuan untuk mengukur keberhasilan agar dapat mengetahui sudah sejauh mana pembelajar memahami suatu program pembelajaran yang sudah diterapkan. Mata kuliah Kanji merupakan mata kuliah yang sulit untuk dipelajari maka dari itu dosen pangajar Kanji melakukan inovasi dan pembaharuan dalam model-model asesmen yang digunakan untuk mengukur kemampuan mahasiswa pembelajar Kanji. Model tes yang digunakan masing-masing dosen pengajar mata kuliah Kanji memiliki bobot tersendiri sesuai dengan tingkatan Kanji yang diajarkan. Model tes dan latihan yang digunakan pengajar Kanji sesuai dengan materi ajar yang sudah diajarkan dan diharapkan mampu meningkatkan motivasi pembelajar Kanji dalam belajar Kanji . 
Model asesmen mata kuliah Kanji di Jurusan Pendidikan Bahasa Jepang dilihat dari model tes yang digunakan dosen pengajar Kanji. Sesuai dengan hasil wawancara yang dilakukan model tes yang digunakan dosen pengajar Kanji memang harus sesuai dengan silabus yang telah tersedia. Model soal yang digunakan pun memliki bobot dan tujuannya masing-masing. Tujuan model tes sesuai dengan teori yang dikemukakan oleh Arikunto (2006) yaitu, memberikan umpan balik kepada pengajar untuk memperbaiki proses pembelajaran, secara sumatif sebagai alat penentu nilai hasil belajar mahasiswa, secara diagnostik yang digunakan sebagai penilaian dimana untuk dapat mengetahui kelemahan pembelajar, bertujuan untuk mengukur keberhasilan agar dapat mengetahui sudah sejauh mana pembelajar memahami suatu program pembelajaran yang sudah diterapkan. Mata kuliah Kanji merupakan mata kuliah yang sulit untuk dipelajari maka dari itu dosen pangajar Kanji melakukan inovasi dan pembaharuan dalam model-model asesmen yang digunakan untuk mengukur kemampuan mahasiswa pembelajar Kanji. Model tes yang digunakan masing-masing dosen pengajar mata kuliah Kanji memiliki bobot tersendiri sesuai dengan tingkatan Kanji yang diajarkan. Model tes dan latihan yang digunakan pengajar Kanji sesuai dengan materi ajar yang sudah diajarkan dan diharapkan mampu meningkatkan motivasi pembelajar Kanji dalam belajar Kanji .

Sesuai dengan buku pedoman Mata kuliah Kanji di Jurusan Pendidikan Bahasa Jepang Universitas Pendidikan Ganesha, mata kuliah Kanji dibagi menjadi 3 mata kuliah berjenjang. Diantaranya Kanji Shokyuu (dasar), Kanji chokyuu (menengah), dan Kanji Jokyuu (atas). Masing-masing mata kuliah Kanji ini memiliki 2 sks. Kanji Shokyuu ditempuh pada semester 2, Kanji menengah ditempuh pada semester 3, Kanji jukyuu ditempuh pada semester 4.

Di dalam analisa masalah pertama mengenai model-model asesmen yang digunakan oleh setiap pengajar dalam mengajar mata kuliah Kanji di jurusan pendidikan bahasa Jepang. Setiap pengajar memiliki model tes yang sama dan juga ada yang berbeda, seperti model tes formatif, model tes melengkapi, dan model tes objektif. Dari model-model asesmen yang dijelaskan tersebut, dapat dijabarkan perbedaan asesmen diantara Kanji Shokyuu, Kanji Chukyuu dan Kanji Jokyuu terdapat dalam isi atau konten dari masingmasing mata kuliah Kanji tersebut. Seperti, urutan Kanji , cara baca Kun Yomi dan On Yomi, mengubah huruf Kanji ke huruf Hiragana, mengubah huruf Hiragana ke huruf Kanji, arti Kanji, melengkapi Kanji yang rumpang, bobot, serta rincian tugas. Perbedaan terdapat pada isi dari masing-masing mata kuliah dan bobot yang dimiliki berbeda sesuai dengan silabus dan RPP yang digunakan masing-masing dosen pengajar Kanji. Dapat dijelaskan isi dari masing-masing mata kuliah Kanji tersebut sebagai berikut.

Urutan Kanji. Dalam mata kuliah Kanji Shokyuu dan chukyuu, dosen pengajar banyak menekankan pada keterampilan menulis Kanji seperti halnya menulis urutan Kanji dengan baik dan benar. Selain tegas mengenai penilaian tentang urutan penulisan Kanji yang baik dan benar, berdasarkan dengan wawancara dengan dosen pengajar mata kuliah Kanji Shokyuu, hal yang juga penting dalam penulisan urutan penulisan Kanji ini adalah keindahan, serta kerapian bentuk Kanji tersebut. Selain itu goresan-goresannya pun juga menjadi salah satu penilaian dalam mata kuliah Kanji Shokyuu ini. Hal ini bertujuan untuk menanamkan kebiasaan menulis Kanji yang baik dan benar agar dalam pembelajaran level Kanji selanjutnya, mahasiswa sudah terbiasa menulis dengan melihat urutan, membuat goresan yang tepat dan menjaga keindahan tulisan Kanji tersebut.

Lain hal nya dalam pembelajaran Kanji level Jokyuu hal hal dasar seperti urutan Kanji, goresan, atau keindahan dalam penulisan Kanji sudah jarang diperhatikan. Hal ini karena dalam pembelajaran Kanji level Jokyuu, pembelajar difokuskan mempelajari kosakata huruf Kanji yang lebih banyak dan levelnya lebih tinggi serta komplek yang menekankan pada kemampuan mengetahui cara baca dan mengubah kosa kata hiragana menjadi huruf Kanji.

Cara baca On Yomi dan Kun Yomi. Cara baca Kanji di Jepang ada dua cara yaitu, cara baca Jepang disebut Kun yomi dan cara baca Cina disebut On Yomi. Kun Yomi dan On Yomi di masing-masng Kanji memiliki jumlah yang berbeda-beda. Hal inilah yang membuat pembelajar Kanji kebingungan dalam memahami arti Kanji yang dipelajari. Pembelajaran mata kuliah Kanji level dasar dan menengah, menempatkan pengetahuan mengenai cara 
baca On Yomi dan Kun Yomi dalam pembelajaran Kanji menjadi sangat penting. Hal ini ditunjukan agar pembelajar Kanji dapat mengusai cara baca Kun Yomi dan On Yomi dalam Kanji dasar dan menengah sebagai keharusan agar dapat memudahkan pembelajar dalam mempelajari Kanji level atas. Di level atas sendiri, penilaian mengenai cara baca terkait On Yomi dan Kun Yomi ini sudah tidak diberikan lagi karena pembelajaran Kanji Jokyuu difokuskan pada membaca kosakata Kanji gabungan dan memperkenalkan arti dari sebuah kata huruf Kanji tersebut.

Mengubah dari huruf hiragana ke Kanji . Asesement penilaian terkait cara mengubah huruf hiragana menjadi huruf Kanji dalam pembelajan Kanji Shokyuu dan Chukyuu menjadi salah satu penilaian yang ditekankan dalam pembelajaran mata kuliah Kanji ini. Lain hal nya dalam level Jokyuu, penilaian mata kuliah Kanji terkait Mengubah huruf hiragana menjadi huruf Kanji menjadi salah satu penilaian yang ditekankan dalam pembelajaran Kanji level atas. Hal ini bertujuan untuk mengetahui tingkat pemahaman pembelajar Kanji mengenai sejauh mana penguasaan Kanji yang sudah dipelajari selama mata kuliah Kanji Shokyuu, Chokyuu dan Jokyuu. Pembelajar atau mahasiswa tidak hanya dituntut untuk bisa membaca huruf Kanji tetapi yang lebih penting adalah menulis huruf Kanji dalam sebuah kata yang ditulis dengan huruf hiragana. Sehingga dengan demikian, tingkat kemahiran mahasiswa dalam mempelajari Kanji level Jokyuu telah dapat dilihat dalam level Kanji ini.

Arti Kanji . Pemahaman dalam pengertian sebuah Kanji menjadi penilaian yang banyak ditemui dalam asesmen mata kuliah Kanji Shokyuu dan Chukyuu. Hal ini juga menjadi hal mendasar yang baik untuk sebuah pemula dalam mengerti arti dari sebuah Kanji sehingga dapat membantu dan mendukung pembelajaran Kanji untuk mempelajari huruf Kanji level Jokyuu yang materi dan jenis Kanji nya lebih komplek dari pada mata kuliah Kanji Shokyuu dan Chukyuu. Dalam mata kuliah Kanji Jokyuu sendiri, mengetahui arti dari sebuah Kanji tidak menjadi sebuah penilaian dalam mata kuliah ini.

Melengkapi Kanji yang rumpang. Salah satu aspek penilaian Kanji yang tidak ada dalam penilaian mata kuliah Kanji Shokyuu adalah melengkapi Kanji yang rumpang. hal ini karena dalam mata kuliah Kanji Shokyuu masih berfokus pada urutan Kanji , maupun cara baca Kanji , tidak berfokus pada penulisan Kanji dari sebuah huruf hiragana. Berbeda hal nya dengan mata kuliah Kanji Chukyuu dan Kanji Jokyuu pembelajar atau mahasiswa sudah dituntut untuk meguasai Kanji dengan lebih baik dan mengetahui Kanji yang kompleks, maka penilaian Kanji terkait melengkapi Kanji yang rumpang menjadi salah satu penilaian yang baik untuk mengetahui sejauh mana pengetahuan pembelajaran tersebut dalam menguasai Kanji Kanji yang sudah mereka pelajari sebelumnya.

Bobot nilai yang diberikan setiap pengajar mata kuliah Kanji juga berbeda beda. Bobot nilai diberikan pada 3 komponen hal yaitu ujian tengah semester, ujian akhir semester dan tugas. Pada Kanji Shokyuu bobot nilai yang paling besar diakumulasikan pada bobot tugas. Tugas tersebut meliputi tes kecil selama perkuliahan, tugas selama perkuliahan dimana aspek penilaian tua ini lebih menekankan pada keindahan penulisan Kanji .

Sedangkan Bobot yang paling besar yang diakumulasikan untuk pembelajaran Kanji Chukyuu dan Jokyuu adalah bobot untuk ujian akhir semester. Ujian akhir semester dipakai pengajar sebagai penentu sebagaiaman pemahaman akhir siswa dalam pembelajaran Kanji Chukyuu atau Jokyuu yang sudah diajarkan selama 1 semseter.

Pada intinya perbedaan Kanji Shokyuu dengan Kanji lainnya dilhat dari beberapa hal yang telah dipaparkan, yang membedakan terletak pada isi dari masing-masing mata kuliah tersebut. dimana Kanji Shokyuu masuk dalam kurikulum baru KKNI. Pada mata kuliah Kanji di Jurusan Pendidikan Bahasa Jepang, Kanji terdiri dari mata kuliah Kanji Shokyuu, Kanji Chukyuu dan Kanji Jokyuu. Masing-masing mata kuliah Kanji memiliki bobot 2 sks. Mata kuliah Kanji memiliki kesulitan yang berbeda disetiap tingkatnnya. Setiap mata kuliah Kanji memiiki model tes yang sama sepeti tes formatif namun ada juga model tes yang berbeda seperti model tes melengkapi dan model tes objektif. Seperti yang sudah dipaparkan dalam model-model tes yang digunakan dosen pengajar Kanji. Pada Kanji Shokyuu dan Kanji chukyuu menggunakan model tes yang sama yaitu model tes formatif dimana bertujuan untuk mengukur sudah sejauh mana mahasiswa memahami mata kliah Kanji yang sudah diajarkan, namun pada Kanji chukyuu juga menggunakan model tes melengkapi tujuannya 
untuk membuat mahasiswa bisa meningat arti Kanji yang telah dipelajari. Pada Kanji Jokyuu lebih menggunakan model tes objektif yang dimana model ini telah dimodifikasi oleh dosen pengajar dalam bentuk soal teka-teki silang, bertujuan untuk melatih daya ingat mahasiswa pada mata kuliah Kanji tersebut. Perbedaanya dari masing-masing mata kuliah Kanji ini terletak pada isi, dan proses pembelajarannya, serta tingkat kesulitannya dari masing-masing mata kuliah tersebut maka model tes yang digunakan seperti yang telah dijabarkan sebelumnya.

Faktor-faktor yang menentukan model tes yang digunakan dosen pengajar Kanji dalam mata kuliah Kanji .

Dalam setiap mata kuliah pasti ada tes dan latihan yang digunakan pengajar untuk mengetahui evaluasi pembelajaran tersebut. Sama dengan dosen pengampu mata kuliah Kanji yang memiliki model tes masing-masing dalam mengetahui evaluasi pembelajaran yang telah diberikan. Faktor-faktor yang menentukkan model tes yang diguakan pengajar Kanji di bagi menjadi dua yaitu, faktor umum dan faktor kusus.

Faktor umum merupakan faktor penentu dari silabus dan RPP yang ada di Jurusan Pendidikan Bahasa Jepang. Faktor umum ini terdiri dari tujuan pembelajaran yang ingin dicapai, ketiga dosen pengajar Kanji memiliki tujuan yang sama yaitu utuk mengetahui sejauh mana mahasiswa memahami dan mengerti mata kliah Kanji yang telah diajarkan. Sedangkan faktor khusus terdiri dari lima aspek yang penting dalam menentukan model tes yang digunakan dosen pengajar Kanji. Adapun aspek-aspek itu ialah, menekankan pada keindahan tulisan, cara baca dan urutan Kanji , menulis arti Kanji , menulis Kanji dengan baik dan benar, dan melengkapi soal rumpang.

Aspek menekankan pada keindahan tulisan, cara baca Kanji , dan memulis arti Kanji digunakan oleh dosen pengajar Kanji Shokyuu, dengan tujuan agar mahasiswa mampu menulis Kanji, dan memahami makna dan arti Kanji yang telah dipelajarinya. Berbeda dengan pengajar Kanji Chukyuu, aspek keindahan tidak lagi menjadi poin utama dalam penilaiannya namun menulis Kanji dengan baik dan benar menjadi salah satu aspek yang digunakan sebagai penentu model tes yang digunakan karena menulis Kanji dengan baik dan benar dapat melatih mahasiswa dalam menulis dan mengingat urutan penulisan Kanji, menulis urutan Kanji dan arti Kanji juga menjadi aspek penting bagi dosen pengajar Kanji Chukyuu serta soal rumpang yang digunakan memliki tujuan agar mengetahui dan dapat mengukur kemampuan mahasiswa dalam pelajaran Kanji yang telah dipelajari. Menurut dosen pengajar Kanji Jokyuu adapun yang menjadi faktor dalam mata kuliah Kanji itu adalah silabus yang mencangkup banyak hal tentang materi ajar dan tujuan pembelajaran. Tujuan pembelajaran pada dosen pengajar Kanji 2 ini menjadi patokan inti dalam penyusunan model tes yang diperlukan. Adapun tujuan pembelajaran yang dosen pengajar Kanji ini tetapkan yaitu, mahasiswa diharapkan mampu menghafal dan membaca Kanji dengan baik dan benar, karena fokus serta tujuan model tes yang dibuat adalah model tes yang mampu menilai kemampuan dalam mengingat kosakata, cara baca maupun makna dari Kanji tersebut. Pada mata kuliah Kanji ini keindahan dalam penulisan Kanji , dan urutan Kanji tidak lagi menjadi fokus utama dalam penilaiannya karena sudah dirasa terlatih di mata kuliah Kanji sebelumnya.

Dapat disimpulkan dari hal yang telah dipaparkan faktor-faktor yang menentukan pemilihan model tes yang digunakan setiap dosen pengajar Kanji yaitu, sama-sama berpatokan pada silabus serta tujuan pembelajaran mata kuliah Kanji ini. Dimana setiap tingkatan pembelajaran Kanji memiliki tujuan yang beragam namun tetap tujuan tersebut sama-sama untuk mengukur kemampuan mahasiswa dalam pembelajaran Kanji .

Setelah memaparkan model-model tes yang digunakan dosen pengajar Kanji dalam mengukur kemampuan mahasiswa dalam mata kuliah Kanji. Ada beberapa faktor yang menjadi penentu dosen pengajar Kanji dalam pembuatan model tes yang digunakan. Faktor-faktor yang menentukan model asesmen atau model tes dan latihan yang digunakan dosen pengajar Kanji salah satunya berpatokan pada silabus mata Kanji di Jurusan Pendidikan Bahasa Jepang UNDIKSHA. Setiap dosen memiliki faktor tertentu dalam pembuatan model asesmen yang digunakan dimana faktor yang menjadi penentu pembuatan model soal ialah beberapa aspek seperti cara baca Kanji dan arti Kanji , urutan 
Kanji , mengisi Kanji yang rumpang dimana aspek ini menjadi faktor penentu soal yang digunakan dosen pengajar Kanji Shokyuu dan Kanji Chukyuu, sedangan aspek penentu yang digunakan dosen pengajar Kanji jukyuu lebih pada aspek tujuan pembelajaran mahasiswa dapat mengingat kosakata Kanji yang sudah diajarkan. Sesungguhnya setiap model asesmen itu memiliki tujuannya masing-masing dalam meningkatkan kemampuan mahasiswa pembelajar Kanji . Ini sesuai dengan teori klasifikasi model tes. Menurut Syaifuddin dimana setiap klasifikasinya memiliki tujuan untuk meningkatkan kemampuan dan mengukur sampai mana pencapaian pelajar atau mahasiswa dalam suatu pembelajaran dan juga mampu memotivasi pembelajar Kanji dari hasil tes yang mereka dapatkan.

\section{Simpulan dan Saran}

Berdasarkan hasil penelitian dapat disimpulkan sebagai berikut.

Model asesmen mata kuliah Kanji yang digunakan oleh dosen pengajar Kanji adalah dalam bentuk tes dan latihan menggunakan model tes formatif. Tetapi ada juga dosen pengajar Kanji menggunakan model tes yang lain seperti, model tes melengkapi dan model tes objektif. Model tes yang digunakan disesuaikan dengan silabus dan tujuan pembelajaran, seperti; dosen pengajar Kanji Shokyuu menggunakan model tes formatif ke dalam tiga bentuk soal yaitu, cara baca Kanji secara Kun Yomi dan On Yomi, urutan Kanji dan cara baca Kanji, dosen pengajar Kanji Chukyuu menggunakan model tes yang sama dengan dosen pengajar mata kuliah Kanji Shokyuu yaitu model tes formatif, tetapi pada bagian keempat, dosen pengajar ini menggunakan model tes melengkapi, agar mahasiswa tidak hanya mampu membaca Kanji namun mampu memahami arti dari Kanji tersebut. Pada dosen pengajar Kanji Jokyuu model yang digunakan adalah model tes formatif dan model tes objektif, yang menekankan pada tujuan pembelajaran yaitu mahasiswa diminta lebih mampu memahami arti dan makna dari beberapa Kanji gabungan.

Pada intinya perbedaan mata kuliah Kanji Shokyuu, Kanji Chukyuu, dan Kanji Jokyuu dilihat dari beberapa aspek berikut, urutan Kanji, cara baca Kun Yomi dan On Yomi, mengubah huruf Kanji ke huruf Hiragana, mengubah huruf Hiragana ke huruf Kanji, arti Kanji, melengkapi Kanji yang rumpang, bobot penilaian, serta rincian tugas. Perbedaan terdapat pada isi dari masing-masing mata kuliah dan bobot penilaian yang dimiliki sesuai dengan silabus dan RPP yang digunakan masing-masing dosen pengajar Kanji. Model asesmen disesuaikan dengan tingkat kesulitan dari masing-masing mata kuliah Kanji tersebut

Dapat disimpulkan bahwa faktor-faktor yang menentukan pemilihan model tes yang digunakan setiap dosen pengajar Kanji adalah, faktor umum dan faktor khusus. Faktor umum adalah faktor yang terdiri dari silabus mata kuliah Kanji di Jurusan Pendidikan Bahasa Jepang. Ketiga dosen tersebut sama-sama berpatokan pada silabus serta tujuan pembelajaran mata kuliah Kanji ini. Sedangkan faktor khusus terdiri dari lima aspek, yaitu, menekankan pada keindahan tulisan, cara baca, urutan Kanji, menulis Kanji dengan baik dan benar, dan melengkapi soal rumpang. berikut.

Berdasarkan hasil penelitian dari simpulan, maka dapat disarankan hal-hal sebagai

Pembelajaran kanji sebaiknya sesuai dengan silabus dan RPP yang sudah ada. Butir soal yang digunakan disesuaian dengan pembelajaran yang diberikan selama perkuliahan. Pelaksanaan kuis atau tes latihan sehari-hari baiknya diberikan secara teratur untuk mengukur kemampuan dan melatih daya ingat mahasiswa tentang Kanji yang telah dipelajari sebelumnya. Soal latihan yang diberikan secata rutin dapat melatih kemampuan mahasiswa dalam memahami dam mengerti Kanji yang telah dipelajari. Hal ini akan berdampak pada nilai akhir pembelajar tersebut.

\section{Daftar Pustaka}

Arikunto, Suharsimi. 2006. Prosedur Penelitian Suatu Pendekatan Praktek. Jakarta: Rineka Cipta. 
Forsythe, Edward. 2015. "Improving Assessment in Japanese University EFL Classes A Model for Implementing Research-Based Language Assessment Practices” . 21st Century Education Forum. Vol. 10 (Maret 2015)

Gunarto. 2010. "Penerapan Asesmen Autentik Dalam Pembelaaran Bahasa Indonesia Di SMP Negeri 2 Delanggu Kabupaten KLATEN" dalam Magistra No. 73 Th. XXII

Ismawati, Esti. 2012. Metode Penelitian Pendidikan Bahasa dan Sastra Indonesia. Yogyakarta: Penerbit Ombak

Japan Foundation. 2012. Survey Report on Japanese-Language Education Abroad 2012. The Japan Foundation: Japan

Pradyani, D.P.S. 2014. "Pengaruh Penerapan Asesmen Kinerja Terhadap Kemampuan Menulis Dalam Bahasa Jepang Dengan Kovariabel Kemampuan Verbal Pada Siswa Kelas XII IPB SMA Negeri 1 Banjarangkan" dalam e-Journal Program Pascasarjana Universitas Pendidikan Ganesha Program Studi Penelitian dan Evaluasi Pendidikan. Volume 4

Poerwanti, E. 2001. Evaluasi pembelajaran, Modul Akta mengajar. UMM Press.

Pedoman Studi Program Sarjana dan Diploma Fakultas Bahasa dan Seni. 2012. Singaraja: Universitas Pendidikan Ganesha

Pedoman Studi Program Sarjana dan Diploma Fakultas Bahasa dan Seni. 2016. Singaraja: Universitas Pendidikan Ganesha

Renariah, Dra., M.Hum. 2002. "Bahasa Jepang dan Karakteristiknya" dalam Kristen Maranatha Vol 1 dan 2 Jurnal Satra Jepang

Rahmat, Pupu Saiful. 2009. "Pendekatan Kualitatif” Volume 5, Nomor 9 (HIm. 1-8)

Suharsimi Arikunto. 2012. Dasar-Dasar Evaluasi Pendidikan. Jakarta: Bumi Aksara.

Sa'dijah, Cholis 2009. Asesmen Kinerja Dalam Pembelajaran Matematika. http://jurnaljpi.files.wordpress.com/2009/09/vol-4-no-2-cholis-sadijah.pdf. (akses: 9 mei 2017)

Sudjianto dan Dahidi, Ahmad. 2004. Pengantar Linguistik Bahasa Jepang. Jakarta: Kesaint Blanc

Sugiyono. 2013. Metode Penelitian Kuantitatif Kualitatif dan R\&D. Bandung: ALFABETA.

Sukardi. 2008. Metodologi Penelitian Pendidikan, Kompetensi dan Praktiknya. Jakarta : PT. Bumi Aksara.

Sundari. Inggit. 2001. "Penerapan Strategi Preview, Question, Read, Reflect, Recite, And Review (PQ4R) Untuk Meningkatkan Kemampuan Membaca Pemahaman Pada Mata Pelajaran Bahasa Indonesia Siswa Kelas VC SDN 60 Kota Bengkulu". Tersedia pada http://repository.unib.ac.id/8821/1/l\%2CII\%2CIII\%2CII-14-ing.FK.pdf (diakses pada 19 Januari 2018)

Toha. Chabib. 1991. Teknik Evaluasi Pendidikan. Jakarta: Raja Grafindo Persada

Tomal, Daniel. R. 2010. Action Research for Edicators Second Edition. Estover Road, Plymouth PL6 7PY, United Kingdom.

Wahyudi. 2012. "Asesmen Pembelajaran Berbasis Portofolio di Sekolah". Jurnal Visi IImu Pendidikan. Tersedia pada http://jurnal.untan.ac.id/index.php/jvip/article/view/370 (diakses pada 12 Maret 2018). 